\title{
REKOMENDASI MODEL PENINGKATAN KEPATUHAN PENGELOLAAN KESEHATAN PASIEN GAGAL GINJAL TERMINAL DI RSUD dr. H. MOH. ANWAR SUMENEP
}

Elyk Dwi Mumpuningtias, Program Studi IImu Keperawatan UNIJA Sumenep, e-mail; mumpuningtias@yahoo.com

\begin{abstract}
Management of patients with end stage renal disease include physical therapy of the underlying disease, treatment of comorbid conditions, replace the renal function by renal replacement therapy. Compliance of health management on end stage renal diseases patients is required. Compliance consists of cognitive and psychomotor components. Cognitively, patient compliance involves understanding and ability to recall the information on medical advice. Compliance in hemodialysis patients affected by patient factors, health care systems and personel factor/provider.

This study was observational design explanative aims to describe and analyzed the factors that affect the health management of compliance in patients with end stage renal disease. The population in this research was all patients with end stage renal disease who undergoing hemodialysis in the hemodialysis unit RSUD dr. H. Moh. Anwar Sumenep. Sampling technique used purposive sampling and obtained a sample of 32 patients in this study. Collecting data used questionnaires and was analyzed using partial least square (PLS). Measurement of inner model used to measure hypothesis with $t$ statistic value $>1,96$.

The result showed that the $t$ statistic value of patients factor was 1,989, health care system was 1,747 and provider factor was 2,933. The statistical result showed that factors of patient and personel factor/provider affected health management compliance.

Improved health management compliance was required in patients with end stage renal disease, especially of patient factors required an understanding of the physical and psychological problems and patient motivation to comply. Enhanced compliance with health management approach based psychoeducation based on King interaction system will improve patient compliance of patients with end stage renal disease undergoing hemodialysis.
\end{abstract}

Keywords: end stage renal disease, hemodialysis, compliance, health management

\section{PENDAHULUAN}

Penatalaksanaan pasien gagal ginjal terminal meliputi terapi fisik terhadap penyakit dasar, terapi terhadap kondisi komorbid, menghambat perburukan fungsi ginjal, terapi pengganti ginjal (Suwitra, 2009). Diperlukan kepatuhan dalam pengelolaan kesehatan agar tidak memperburuk kondisi pasien gagal ginjal terminal. Kepatuhan pasien hemodialisis dipengaruhi oleh faktor pasien, sistem pelayanan kesehatan dan faktor petugas/provider (Saran, et al., 2003; Loghman-Adham, 2003; Kammerer, et al., 2007).

Prevalensi ketidakpatuhan pembatasan cairan pada pasien hemodialisis di Amerika Serikat bervariasi antara 12,5-96,8\%. Faktor risiko terbanyak yaitu usia muda, perokok, dan hidup sendiri tanpa keluarga. Ketidakpatuhan dalam pembatasan asupan kalium dan fosfor diperkirakan 19-57\%. Ketidakpatuhan dalam pengobatan berkisar antara 19-99\% (Ghimire et al., 2015).
Ketidakpatuhan terhadap pengelolaan kesehatan yang mencakup keteraturan hemodialisis, pembatasan cairan, pembatasan diet dan program pengobatan merupakan masalah yang umum pada pasien gagal ginjal terminal yang menjalani hemodialisis. Tanda ketidakpatuhan dalam pengelolaan kesehatan dapat diketahui dengan peningkatan IDWG (Interdialytic Weight Gain) dan peningkatan kalium darah. Ketidakpatuhan pembatasan diet protein mengakibatkan penimbunan substansi nitrogen dan ion anorganik lain karena kelebihan protein dipecah menjadi urea dan mengakibatkan uremia. Ketidakpatuhan pembatasan cairan dapat menyebabkan edema dan komplikasi kardiovaskuler. Ketidakpatuhan tersebut dapat menyebabkan kondisi pasien menjadi kritis bahkan dan dapat meningkatkan angka morbiditas serta mortalitas (Denhaerynk et al., 2007). Ketidakpatuhan memiliki dampak yang sangat memprihatinkan sebab akan berpengaruh terhadap terjadinya komplikasi akut dan kronis, lamanya perawatan akan 
berdampak pada produktivitas dan menurunkan sumber daya manusia. Dampak masalah ini bukan hanya mengenai individu dan keluarga saja, namun juga akan berdampak pada sistem kesehatan suatu negara. Negara akan mengeluarkan biaya yang banyak untuk mengobati dan merawat pasien gagal ginjal terminal dengan hemodialisis yang umumnya menjadi pengobatan seumur hidup.

Model peningkatan kepatuhan yang sudah diterapkan di unit hemodialisis RSUD dr. $H$. Moh. Anwar Sumenep yaitu pemberian pendidikan kesehatan pada pasien pada saat sesi hemodialisis. Pendidikan kesehatan yang telah dilakukan masih belum optimal terbukti dari hasil studi pendahuluan masih banyak pasien yang belum patuh terhadap pengelolaan kesehatan.

Pengembangan model menggunakan psikoedukasi dengan pendekatan sistem konseptual King, didasarkan pada asumsi bahwa fokus keperawatan adalah manusia. King menggunakan pendekatan sistem terbuka dalam hubungan interaksi yang konstan dengan lingkungan dengan kesehatan sebagai tujuannya. King mengemukakan konsep kerjanya yang meliputi adanya sistem personal, sistem interpersonal dan sistem sosial yang saling berhubungan satu dengan yang lain untuk mencapai tujuan yang diharapkan. (Tomey \& Alligood, 2006).

Pengembangan model yang dapat mengoptimalkan asuhan keperawatan pada pasien gagal ginjal terminal yang berfokus pada sistem interaksi dinamis diperlukan untuk meningkatkan kepatuhan pengelolaan kesehatan. Pendekatan dynamic interacting system diharapkan dapat mengakomodasi psikoedukasi pasien gagal ginjal, sehingga Tabel 1 Tabulasi silang karakteristik pasien dengan terminal di unit hemodialisis RSUD dr. H. Mo dapat meningkatkan kepatuhan pengelolaan kesehatan.

\section{METODE}

Desain yang digunakan dalam penelitian ini adalah explanative observational dengan pendekatan cross sectional. Populasi dalam penelitian ini yaitu seluruh pasien gagal ginjal terminal yang menjalani hemodialisis di unit hemodialisis RSUD dr. $\mathrm{H}$. Moh. Anwar Sumenep. Besar sampel dalam penelitian ini yaitu 32 responden. Pemilihannya dipilih dengan purposive sampling didapatkan 31 perawat. Data dikumpulkan menggunakan kuisioner.

Analisis dilakukan dengan menggunakan Partial Least Square (PLS). Hasil PLS dan isu strategis kemudian diangkat ke dalam FGD dengan tujuan untuk menyusun modul peningkatan kepatuhan pengelolaan kesehatan pasien gagal ginjal terminal. Peserta kegiatan FGD terdiri dari pasien yang menjalai hemodialisis di unit hemodialisis RSUD dr. $\mathrm{H}$. Moh. Anwar Sumenep yang dipilih berdasarkan purposive sampling dan yang berjumlah 7 orang.

\section{HASIL}

Hasil penelitian menjelaskan tentang faktor yang mempengaruhi kepatuhan pengelolaan kesehatan pasien gagal ginjal terminal yang menjalani hemodialisis meliputi faktor pasien, faktor sistem pelayanan kesehatan dan faktor petugas/provider.

Asosiasi karakteristik pasien dengan kepatuhan pengelolaan kesehatan pasien gagal ginjal terminal di unit hemodialisis RSUD dr. $\mathrm{H}$. Moh. Anwar Sumenep dapat dilihat pada tabulasi silang tabel 1. kepatuhan pengelolaan kesehatan pasien gagal ginjal

\begin{tabular}{|c|c|c|c|c|c|c|c|}
\hline \multirow{3}{*}{$\begin{array}{l}\text { Karakteristik } \\
\text { pasien }\end{array}$} & \multirow{3}{*}{ Kategori } & \multicolumn{4}{|c|}{ Kepatuhan pengelolaan kesehatan } & \multirow{2}{*}{\multicolumn{2}{|c|}{ Total }} \\
\hline & & \multicolumn{2}{|c|}{ Tidak patuh } & \multicolumn{2}{|c|}{ Patuh } & & \\
\hline & & $\mathrm{F}$ & $\%$ & $f$ & $\%$ & $\mathrm{~N}$ & $\%$ \\
\hline \multirow[t]{2}{*}{ Jenis Kelamin } & Laki-laki & 5 & 15,6 & 14 & 43,8 & 19 & 59,4 \\
\hline & Perempuan & 6 & 18,8 & 7 & 21,9 & 13 & 40,6 \\
\hline \multirow{6}{*}{ Usia } & 17-25 tahun & 0 & 0 & 1 & 31,1 & 1 & 31,1 \\
\hline & 26-35 tahun & 0 & 0 & 1 & 31,1 & 1 & 31,1 \\
\hline & $36-45$ tahun & 1 & 31,1 & 6 & 18,8 & 7 & 21,9 \\
\hline & 46-55 tahun & 3 & 9,4 & 5 & 15,6 & 8 & 25 \\
\hline & 56-65 tahun & 5 & 15,6 & 6 & 18,8 & 11 & 34,4 \\
\hline & $>65$ tahun & 2 & 6,2 & 2 & 6,2 & 4 & 12,5 \\
\hline \multirow{3}{*}{$\begin{array}{l}\text { Tingkat } \\
\text { pendidikan }\end{array}$} & Pendidikan dasar (SD-SMP) & 5 & 15,6 & 10 & 31,2 & 15 & 46,9 \\
\hline & SMA & 2 & 6,2 & 10 & 31,2 & 12 & 37,5 \\
\hline & PT & 4 & 12,5 & 1 & 3,1 & 5 & 15,6 \\
\hline \multirow{2}{*}{$\begin{array}{l}\text { Status } \\
\text { perkawinan }\end{array}$} & Kawin & 11 & 34,4 & 19 & 59,4 & 30 & 93,8 \\
\hline & Belum kawin & 0 & 0 & 2 & 6,2 & 2 & 6,2 \\
\hline
\end{tabular}


Responden dengan jenis kelamin perempuan lebih banyak yang tidak patuh terhadap pengelolaan kesehatan. Ketidakpatuhan lebih banyak pada responden dengan rentang umur 56-65 tahun dengan tingkat pendidikan dasar. Sebagian besar

Tabel 2 Tabulasi silang faktor pasien dengan kepatuhan pengelolaan kesehatan pasien gagal ginjal terminal di unit hemodialisis RSUD dr. H. Moh. Anwar Sumenep

\begin{tabular}{|c|c|c|c|c|c|c|c|}
\hline \multirow{3}{*}{ Faktor Pasien } & \multirow{3}{*}{ Kategori } & \multicolumn{4}{|c|}{ Kepatuhan pengelolaan kesehatan } & \multirow{2}{*}{\multicolumn{2}{|c|}{ Total }} \\
\hline & & \multicolumn{2}{|c|}{ Tidak Patuh } & \multicolumn{2}{|c|}{ Patuh } & & \\
\hline & & f & $\%$ & $f$ & $\%$ & $\mathrm{~N}$ & $\%$ \\
\hline \multirow[t]{2}{*}{ Motivasi } & Kurang & 10 & 31,15 & 5 & 15,6 & 15 & 46,9 \\
\hline & Baik & 1 & 3,1 & 16 & 50 & 17 & 53,1 \\
\hline \multirow{4}{*}{ Lama hemodialisis } & $<13$ bulan & 3 & 9,4 & 9 & 28,1 & 12 & 37,5 \\
\hline & 13-24 bulan & 5 & 15,6 & 8 & 25 & 13 & 40,6 \\
\hline & $25-36$ bulan & 1 & 31,1 & 4 & 12,5 & 5 & 15,6 \\
\hline & $>36$ bulan & 2 & 6,2 & 0 & 0 & 2 & 6,2 \\
\hline \multirow{2}{*}{ Tingkat pengetahuan } & Rendah & 2 & 6,2 & 6 & 18,8 & 8 & 25 \\
\hline & Tinggi & 9 & 28,1 & 15 & 46,9 & 24 & 75 \\
\hline \multirow[t]{2}{*}{ Persepsi pasien } & Kurang & 3 & 9,4 & 6 & 18,8 & 9 & 28,1 \\
\hline & Baik & 8 & 25 & 15 & 46,9 & 23 & 71,9 \\
\hline
\end{tabular}
lebih banyak didapatkan pada responden dengan tinggkat motivasi kurang. Responden dengan tingkat pengetahuan tinggi sebagian besar patuh terhadap pengelolaan kesehatan. Responden yang memiliki persepsi tentang pelayanan perawat baik sebagian besar patuh terhadap pengelolaan kesehatan. Berdasarkan

lama hemodialisis, ketidakpatuhan
penngelolaan kesehatan banya didapatkan pada responden yang berada pada rentang rentang lama hemodialisis 13-24 bulan.

Asosiasi faktor sistem pelayanan kesehatan dengan kepatuhan pengelolaan kesehatan dapat dilihat pada tabulasi silang tabel 3

Tabel 3 Tabulasi silang faktor sistem pelayanan kesehatan dengan kepatuhan pengelolaan kesehatan pasien gagal ginjal terminal di unit hemodialisis RSUD dr. H. Moh. Anwar Sumenep

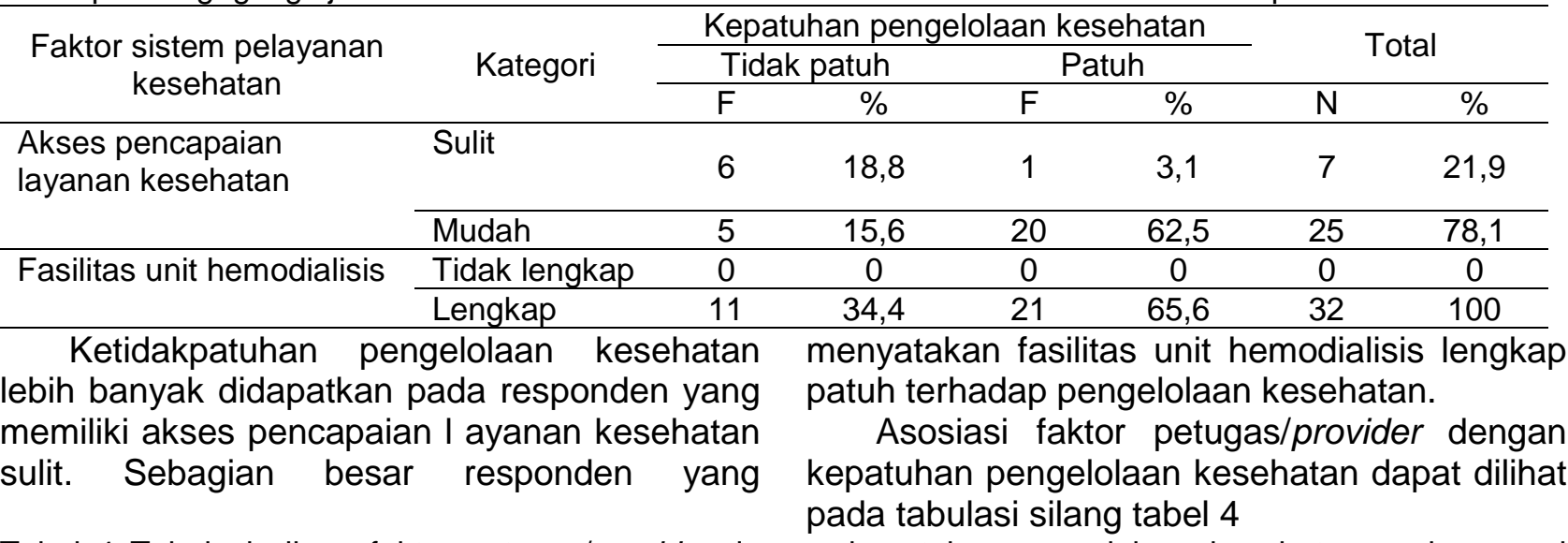

Tabel 4 Tabulasi silang faktor petugas/provider dengan kepatuhan pengelolaan kesehatan pasien gagal ginjal terminal di unit hemodialisis RSUD dr. H. Moh. Anwar Sumenep

\begin{tabular}{|c|c|c|c|c|c|c|c|}
\hline \multirow{3}{*}{ Faktor sistem petugas/provider } & \multirow{3}{*}{ Kategori } & \multicolumn{4}{|c|}{ Kepatuhan pengelolaan kesehatan } & \multirow{2}{*}{\multicolumn{2}{|c|}{ Total }} \\
\hline & & & atuh & & & & \\
\hline & & $f$ & $\%$ & $\mathrm{~F}$ & $\%$ & $\mathrm{~N}$ & $\%$ \\
\hline \multirow[t]{3}{*}{ Kualitas komunikasi } & Kurang & 0 & 0 & 0 & 0 & 0 & 0 \\
\hline & Cukup & 4 & 12,5 & 2 & 6,2 & 6 & 18,8 \\
\hline & Baik & 7 & 21,9 & 19 & 59,4 & 26 & 81,2 \\
\hline
\end{tabular}

Kepatuhan pengelolaan kesehatan sebagian menyatakan kualitas komunikasi antara pasien besar didapatkan pada responden yang dengan perawat

baik 
Pengembangan Model Peningkatan Kepatuhan Pengelolaan Kesehatan Pasien Gagal Ginjal Terminal

Hasil evaluasi outer model nilai convergen validity dapat dilihat pada gambar dan tabel berikut:

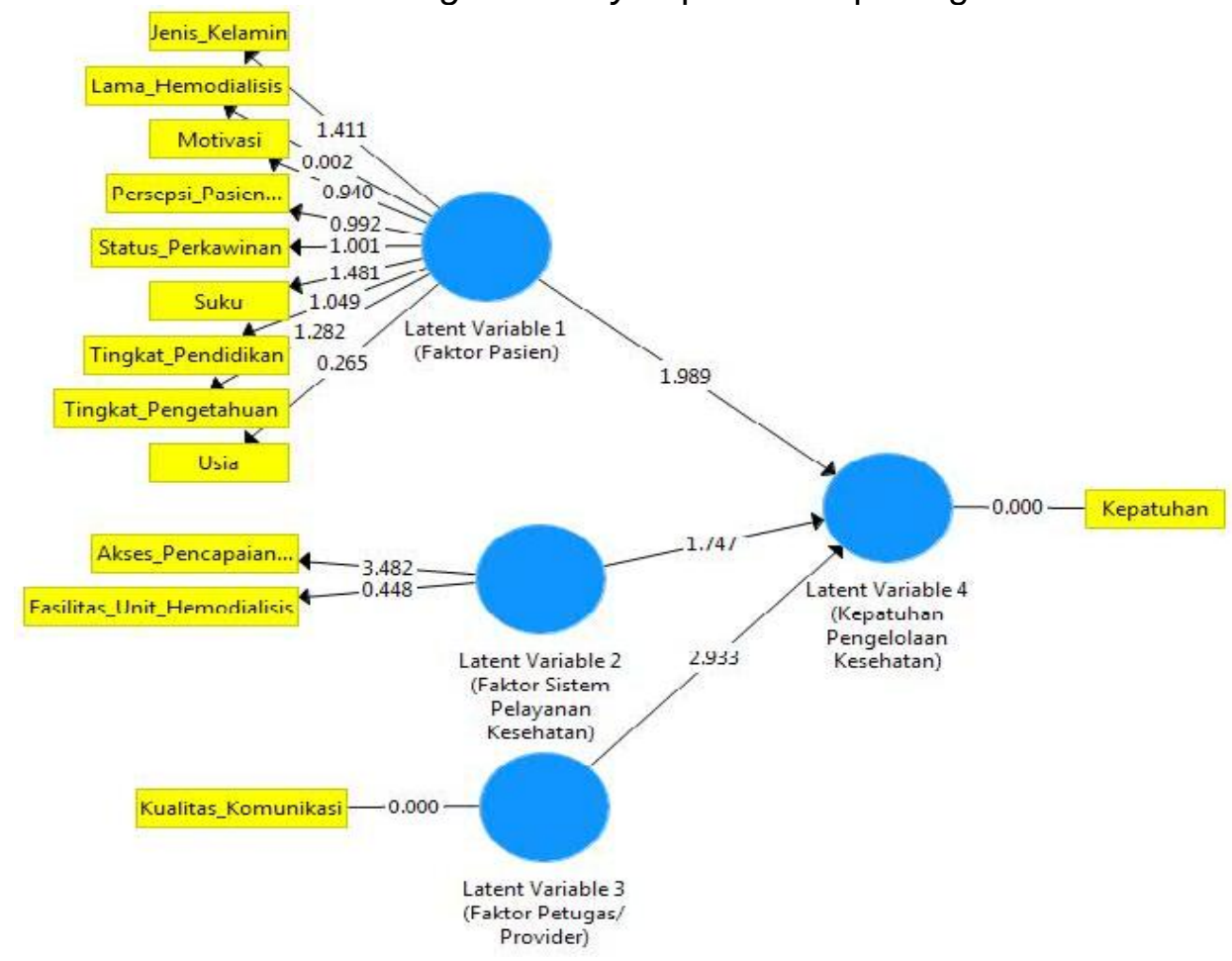

Gambar 1 Path model dan nilai outer loading pada pengembangan model peningkatan kepatuhan pengelolaan kesehatan pasien gagal ginjal terminal

Nilai outer loading untuk semua indikator baik dari indikator untuk variabel laten seperti faktor pasien, faktor sistem pelayanan

kesehatan, dan faktor petugas/provider dapat dilihat pada tabel berikut:

Tabel 5 Hasil validitas konvergen pengembangan model peningkatan kepatuhan pengelolaan kesehatan pasien gagal ginjal terminal

\begin{tabular}{lllcc}
\hline No. & \multicolumn{1}{c}{ Variabel } & \multicolumn{1}{c}{ Indikator } & $\begin{array}{c}\text { Outer } \\
\text { loading }\end{array}$ & Keterangan \\
\hline 1 & Faktor pasien & X1.1 Usia & 0,265 & Tidak valid \\
& & X1.2 Jenis kelamin & 1,411 & Valid \\
& & X1.3 Status perkawinan & 1,001 & Valid \\
& & X1.4 Suku & 1,481 & Valid \\
& & X1.5 Tingkat pendidikan & 1,049 & Valid \\
& & X1.6 Lama hemodialisis & 0,002 & Tidak valid \\
& & X1.7 Tingkat pengetahuan & 1,282 & Valid \\
& & X1.8 Motivasi & 0,940 & Valid \\
& & X1.9 Persepsi pasien tentang pelayanan perawat & 0,992 & Valid \\
\hline 2 & Faktor sistem & X2.1 Fasilitas unit HD & 0,448 & Tidak valid \\
& pelayanan & X2.2 Akses pencapaian layanan kesehatan & 3,482 & Tidak valid \\
& kesehatan & & & \\
\hline 3 & Faktor & X3.1 Kualitas komunikasi & 0,000 & Tidak valid \\
& petugas/provider & & & \\
\hline
\end{tabular}

Berdasarkan tabel di atas dapat diketahui bahwa terdapat beberapa indikator yang tidak valid yaitu persepsi pasien terhadap pelayanan perawat, fasilitas unit hemodialisis, akses pencapaian layanan kesehatan dan kualitas komunikasi. Indikator yang tidak valid tersebut menunjukkan bahwa indikator di dalam struktural telah memenuhi uji validitas.

Hasil Composite reliability untuk menguji nilai reliabilitas indikator pada penelitian ini dapat dilihat pada tabel 6 . dapat direduksi karena nilai outer loading $<0,5$. Indikator yang nilai outer loading $>0,5$ 
Tabel 6 Hasil composite reliability dan cronbach alpha pengembangan model peningkatan kepatuhan pengelolaan kesehatan pasien gagal ginjal terminal

\begin{tabular}{llccc}
\hline No & \multicolumn{1}{c}{ Variabel } & $\begin{array}{c}\text { Composite } \\
\text { reliability }\end{array}$ & Cronbach alpha & Keterangan \\
\hline 1 & Faktor pasien & 0,534 & 0,272 & Tidak reliabel \\
2 & Faktor sistem pelayanan kesehatan & 0,600 & 0,305 & Tidak reliabel \\
3 & Faktor petugas/provider & 1,000 & 1,000 & Reliabel \\
\hline
\end{tabular}

Berdasarkan tabel di atas nilai composite disimpulkan bahwa hanya variabel faktor reliability dan cronbachs alpha tidak semua petugas/provider telah memenuhi uji reliabilitas. variabel menunjukkan $>0,7$ sehingga dapat Hasil evaluasi inner model untuk menguji hipotesis penelitian dapat dilihat pada tabel 7

Tabel 7 Hasil uji hipotesis pengembangan model peningkatan kepatuhan pengelolaan kesehatan pasien gagal ginjal terminal

\begin{tabular}{llll}
\hline No. & \multicolumn{1}{c}{ Variabel } & \multicolumn{1}{c}{$t$ statistic } & \multicolumn{1}{c}{ Keterangan } \\
\hline 1 & $\begin{array}{l}\text { Pengaruh faktor pasien terhadap kepatuhan } \\
\text { pengelolaan kesehatan pasien gagal ginjal terminal }\end{array}$ & 1,989 & Ada pengaruh \\
\hline 2 & $\begin{array}{l}\text { Pengaruh faktor sistem pelayanan kesehatan terhadap } \\
\text { kepatuhan pengelolaan kesehatan pasien gagal ginjal } \\
\text { terminal }\end{array}$ & 1,747 & $\begin{array}{l}\text { Tidak ada } \\
\text { pengaruh }\end{array}$ \\
\hline 3 & $\begin{array}{l}\text { Pengaruh faktor petugas/provider terhadap kepatuhan } \\
\text { pengelolaan kesehatan pasien gagal ginjal terminal }\end{array}$ & 2,933 & Ada pengaruh \\
\hline
\end{tabular}

Berdasarkan tabel di atas menunjukkan bahwa faktor pasien dan faktor petugas/provider mempengaruhi kepatuhan pengelolaan kesehatan pasien gagal ginjal terminal sedangkan faktor sistem pelayanan kesehatan tidak mempengaruhi kepatuhan pengelolaan kesehatan pasien gagal ginjal terminal.

Penentuan isu strategis didasarkan dari hasil analisis partial least square, skor di atas median, dan jawaban responden pada pernyataan kuesioner. Isu strategis yang didapatkan dan akan dipaparkan dalam FGD yaitu faktor pasien (jenis kelamin, status perkawinan, tingkat pendidikan, motivasi, tingkat pengetahuan, persepsi pasien tentang pelayanan perawat) dan faktor petugas/provider yaitu kualitas komunikasi.

\section{Rekomendasi dari hasil FGD}

Rekomendasi dari FGD dan diskusi pakar tentang bentuk model pengembangan kepatuhan pengelolaan kesehatan pasien gagal ginjal terminal di RSUD dr. H. Moh. Anwar Sumenep yaitu:

1. Menyusun jadwal pemberian pendidikan kesehatan tentang gagal ginjal terminal dan pengelolaan kesehatannya

2. Menyusun tujuan bersama dan membuat kontrak dengan pasien tentang perubahan perilaku mematuhi anjuran tenaga kesehatan terkait pengelolaan kesehatan pasien gagal ginjal terminal.

3. Menentukan role model (sesama pasien gagal ginjal terminal) untuk membagikan pengalaman terkait pegelolaan kesehatan

pasien gagal ginjal terminal yang menjalani hemodialisis.

\section{PEMBAHASAN}

\section{Faktor Pasien terhadap Kepatuhan Pengelolaan Kesehatan}

Hasil penelitian ini menunjukkan bahwa proporsi responden berdasarkan jenis kelamin didapatkan lebih banyak responden laki-laki (59\%) dibandingkan responden perempuan. Responden laki-laki lebih banyak yang patuh dibandingkan (14 responden) responden perempuan. Sesuai dengan penelitian oleh Syamsiah, 2011 memperlihatkan bahwa responden laki-laki memiliki peluang untuk lebih patuh sebesar 1,401 kali dibandingkan dengan responden perempuan. Hal tersebut dikarenakan perempuan umumnya dipengaruhi banyak faktor dalam mempertahankan suatu perilaku disamping biasanya perempuan lebih labil dibandingkan laki-laki lebih stabil dalam mempertahankan keyakinan maupun perilakunya.

Hasil penelitian ini menujukkan sebagian besar responden berada pada rentang usia 5565 tahun. Responden dengan usia paling muda hanya satu responden. Responden dengan usia paling muda kurang patuh terhadap pengelolaan kesehatannya. Usia yang semakin meningkat akan meningkatkan pula kemampuan seseorang dalam mengambil keputusan, berfikir rasional, mengendalikan emosi, toleran dan semakin terbuka terhadap pandangan orang lain. Usia dewasa pada umumnya merupakan seseorang yang aktif dengan memiliki fungsi peran yang banyak, mulai dari perannya sebagai dindividu itu 
sendiri, keluarga, di tempat kerja, maupun dalam kelompok-kelompok sosial mereka (Kurniasih et al., 2015).

Hasil penelitian menunjukkan sebagian besar tingkat pendidikan responden yaitu pendidikan dasar setara SD dan SMP. Berdasarkan hasil penelitian responden dengan tingkat pendidikan dasar yang tidak patuh 6 dari 15 responden, tingkat pendidikan menengah 3 dari 12 responden dan tingkat pendidikan tinggi 4 dari 5 responden. Responden dengan pendidikan lebih tinggi tidak selalu mematuhi pengelolaan kesehatan dibandingkan dengan responden dengan pendidikan yang lebih rendah. Hal ini bisa disebabkan karena tingkat pendidikan yang ditempuh berbeda dengan disiplin ilmu tentang kesehatan sehingga pemahaman tentang kepatuhan pengelolaan kesehatan sulit untuk dipahami dan menyebabkan tingginya tingkat pendidikan tidak berhubungan dengan kepatuhan pengelolaan kesehatan.

Hasil penelitian menunjukkan sebagian besar responden (41\%) telah menjalani hemodialisis antara 13-24 bulan. Berdasarkan lama hemodialisis responden yang lebih lama menjalani hemodialisis cenderung kurang mematuhi pengelolaan kesehatan. Periode sakit dapat mempengaruhi kepatuhan. Beberapa penyakit yang tergolong penyakit kronik, banyak mengalami masalah kepatuhan. Pengaruh sakit yang lama, dan perubahan pola hidup, serta komplikasi-komplikasi yang sering muncul sebagai dampak sakit yang lama mempengaruhi bukan hanya pada fisik pasien, namun juga emosional, psikologis dan sosial pasien.

Hasil penelitian menunjukkan bahwa responden dengan pengetahuan hemodialisis yang tinggi lebih banyak dibandingkan dengan responden dengan pengetahuan yang rendah. Responden yang memiliki pengetahuan hemodialisis tinggi sebesar 24 (75\%), sedangkan responden yang memiliki pengetahuan rendah sebesar 8 (25\%). Proporsi kepatuhan didapatkan lebih besar pada responden yang berpengetahuan tinggi dibandingkan dengan responden yang berpengetahuan hemodialisis rendah. Responden dengan tingkat pengetahuan tinggi namun tidak patuh disebabkan karena motivasi yang kurang. Motivasi pasien untuk patuh kurang disebabkan bukan disebabkan karena ketidaktahuannya tentang pengelolaan kesehatan pasien gagal ginjal terminal melainkan berasal dari internal pasien yang beranggapan bahwa penyakitnya merupakan takdir dari yang Maha Kuasa sehingga ketika terjadi permasalahan yang disebabakan ketidakpatuhan kondisi psikologis pasien tidak akan terganggu.

Berdasarkan hasil penelitian didapatkan hasil 17 responden $(53,1 \%)$ memiliki motivasi baik sedangkan 15 responden (46,9\%) memiliki motivasi kurang. Berdasarkan data hasil tabulasi silang antara motivasi dengan kepatuhan pengelolaan kesehatan didapatkan data sebagian besar responden yang patuh memiliki motivasi yang baik sebanyak 16 responden $(50 \%)$. Hanya 1 orang responden yang memiliki motivasi baik namun tidak patuh terhadap pengelolaan kesehatan. Ketidakpatuhan tersebut berupa tidak teratur datang hemodialisis dikrenakan akses pencapaian layanan kesehatan yang sulit. Tempat tinggal pasien jauh dari unit hemodialisis dan pasien mengalami kesulitan dalam biaya transportasi. Transportasi dan biaya merupakan salah satu faktor eksternal yang mempengaruhi kepatuhan pasien. Semakin jauh jarak rumah pasien dari tempat pelayanan kesehatan dan sulitnya transportasi maka menyebabkan pasien tidak rutin dan teratur datang hemodialisis sesuai yang telah dijadwalkan.

Berdasarkan hasil penelitian menunjukkan 23 respoden $(71,9 \%)$ memiliki persepsi terhadap pelayanan perawat yang baik. Berdasarkan hasil tabulasi silang antara persepsi pasien tentang pelayanan perawat dengan kepatuhan pengelolaan kesehatan sebanyak 15 responden (46,9\%) patuh terhadap pengelolaan kesehatan memiliki persepsi baik. Responden menyatakan dengan sengaja tidak membatasi asupan cairan dan pola makan yang benar sehari sebelum hemodialisis dengan anggapan setelah hemodialisis kondisi badannya menjadi optimal kembali.

\section{Faktor Sistem Pelayanan Kesehatan terhadap Pengelolaan Kesehatan}

Unit hemodialisis merupakan bagian dari pelayanan kesehatan rawat jalan di RSUD dr. $H$. Moh. Anwar Sumenep. Unit hemodialisis RSUD dr. H. Moh. Anwar Sumenep memiliki fasilitas tujuh unit mesin hemodialisis, tersedia peralatan medis sesuai dengan kebutuhan, sterilisator dan tersedia tempat pengolahan air hemodialisis.

Hasil penelitian menunjukkan bahwa lebih banyak responden yang memiliki akses pelayanan kesehatan yang mudah dibandingkan dengan akses pelayanan 
kesehatan yang sulit. Responden yang memiliki akses sulit sebesar 7 (22 \%), sedangkan responden yang memiliki akses mudah sebesar 25 (78\%). Proporsi kepatuhan didapatkan lebih besar pada responden dengan akses yang mudah dibndingkan dengan responden yang memiliki akses yang sulit. Responden dengan akses sulit dikarenakan responden berdomisili di pulau di luar daratan pulau Madura sehingga memerlukan waktu yang cukup lama untuk mencapai unit hemodialisis. Akses pencapaian layanan kesehatan merupakan faktor penting yang dapat mendukung kepatuhan pengelolaan kesehatan pasien gagal ginjal terminal yang menjalani hemodialisis. Kemudahan sarana prasarana dan biaya transportasi merupakan faktor utama kemudahan pencapaian layanan kesehatan.

\section{Faktor Petugas/Provider: Kualitas Komunikasi terhadap Kepatuhan Pengelolaan Kesehatan}

Petugas kesehatan yang bertugas di unit hemodialisis RSUD dr. $\mathrm{H}$. Moh. Anwar Sumenep terdiri dari dokter spesialis penyakit dalam, perawat dan tenaga penunjang medis. Berdasarkan PMK No. 182 tentang penyelenggaraan pelayanan dialisis pada fasilitas pelayanan kesehatan persyaratan tenaga perawat yaitu perawwat mahir hemodialisis minimal sebanyak 3 orang perawat untuk 4 mesin hemodialisisis dari organisasi profesi.

Hasil penelitian menunjukkan kualitas komunikasi antara perawat dengan pasien sebagian besar baik. Tidak ada responden yang menyatakan kualitas komunikasi yang kurang antara perawat dengan pasien. Komunikasi, informasi dan edukasi (KIE) diberikan oleh perawat saat proses hemodialisis berlangsung. KIE yang dilakukan perawat belum terstruktur dalam standart operasional prosedur.

Salah satu faktor paling penting yang mempengaruhi kepatuhan adalah hubungan pasien dengan petugas dialisis. DOOPS menunjukkan hubungan yang rendah antara seorang ahli diet dalam hal ketidakpatuhan $(\mathrm{OR}=0,75, p$ value $=0,08)$ (Kammerer, 2007). Dukungan profesional kesehatan sangat diperlukan untuk meningkatkan kepatuhan, misalnya dalam hal teknik komunikasi. Peran perawat pada pasien yang menjalani hemodialisis salah satunya dengan memberikan pelayanan keperawatan terhadap pasien tentang pentingnya hemodialisis untuk kesehatannya, menyarankan untuk tetap rutin menjalani hemodialisis, memberikan perhatian dan selalu melakukan interaksi dan komunikasi dengan pasien.

\section{Rekomendasi Model Peningkatan Kepatuhan Pengelolaan Kesehatan Pasien Gagal Ginjal Terminal di Unit Hemodialisis RSUD dr. H. Moh. Anwar Sumenep}

Rekomendasi model terdiri dari empat tahap yaitu: 1) penjadwalan pemberian pendidikan kesehatan terkait gagal ginjal terminal; 2) penyusunan tujuan bersama dan kontrak perubahan perilaku; 3) menentukan sesama pasien sebagai role model untuk berbagi pengalaman tentang pengelolaan kesehatan pasien gagal ginjal terminal yang menjalani hemodialisis; 4) evaluasi kepatuhan pengelolaan kesehatan pasien gagal ginjal terminal yang menjalani hemodialisis.

\section{SIMPULAN DAN SARAN \\ Simpulan}

1. Karakteristik pasien, lama hemodialisis, motivasi dan tingkat pengetahuan merupakan faktor pasien yang mempengaruhi kepatuhan pengelolaan kesehatan pasien gagal ginjal terminal yang menjalani hemodialisis di unit hemodialisis RSUD dr. H. Moh. Anwar Sumenep.

2. Faktor sistem pelayanan kesehatan yang terdiri dari fasilitas unit hemodialisis dan akses pencapaian pelayanan kesehatan tidak mempengaruhi kepatuhan pengelolaan kesehatan pasien gagal ginjal terminal yang menjalani hemodialisis di unit hemodialisis RSUD dr. H. Moh. Anwar Sumenep.

3. Faktor petugas/provider yaitu kualitas komunikasi petugas hemodialisis mempengaruhi kepatuhan pengelolaan kesehatan pasien gagal ginjal terminal yang menjalani hemodialisis di unit hemodialisis RSUD dr. H. Moh. Anwar Sumenep.

4. Rekomendasi model peningkatan kepatuhan pengelolaan kesehatan pasien gagal ginjal terminal yang menjalani hemodialisis di unit hemodialisis RSUD dr. H. Moh. Anwar Sumenep dibuat berdasarkan hasil focus group discussion dan diskusi pakar. Model peningkatan kepatuhan terdiri dari penjadwalan pemberian pendidikan kesehatan, penyusunan tujuan bersama dan kontrak perubahan perilaku pasien, dan menentukan sesama pasien sebagai role model untuk berbagi pengalaman tentang pengelolaan kesehatan pasien gagal ginjal yang menjalani hemodialisis. 


\section{Saran}

1. Pasien gagal ginjal terminal

Pasien gagal ginjal terminal selalu bergantung pada hemodialisis hendaknya selalu mematuhi anjuran medis dan patuh terhadap pengelolaan kesehatan mencakup pembatasan cairan, pola diit yang benar, hemodialisis teratur, dan minum obat teratur.

2. Perawat

Perawat sebagai salah satu tenaga kesehatan yang mempunyai peranan penting dalam kepatuhan pengelolaan kesehatan pasien dapat memaksimalkan perannya dengan meningkatkan kuantitas interaksi dengan pasien yang bertujuan untuk mengingatkan kembali informasi yang telah diberikan dengan melakukan recall dan pengulangan kembali informasi. Kualitas komunikasi dalam pemberian pendidikan kesehatan juga perlu ditingkatkan dalam upaya peningkatan kepatuhan pengelolaan kesehatan.

3. Institusi pelayanan kesehatan

Rumah sakit sebagai institusi pelayanan kesehatan yang melakukan tindakan hemodialisis diharapkan dapat membuat standar operasional prosedur perawatan pasien gagal ginjal terminal yang menjalani hemodialisis untuk menigkatkan kepatuhan sehingga dapat meningkatkan mutu pelayanan keperawatan rumah sakit.

4. Peneliti selanjutnya

Melibatkan perawat dalam focus group discussion dan penyusunan modul

Menguji coba rekomendasi model yang telah dibuat di tempat penelitian yang sama atau di tempat lain yang memiliki karakteristik pasien gagal ginjal terminal yang hampir sama, sehingga modul yang telah disusun dapat diterapkan.

\section{DAFTAR PUSTAKA}

Alikari, V, Matziou, V, Tsironi, M, Theofilou, P, \& Zyga, S, 2015, The effect of nursing counseling on iproving knowledge, aherence to treatment and quality of life of patients undergoing hemodialysis, International Journal of caring Sciences, 514-519.

Bordbar, M \& Faridhossieni, F, 2012, Psychoeducation for bipolar mood, Clinical, Research and Treatment Approaches to Affective, 13(2), 102-115.

Brown, NW 2011, Psychoeducational groups: process and practice, 3rd ed, New York: Routledge.
Dahlan, M, 2013, Besar sampel dan cara pengambilan sampel dalam penelitian kedokteran dan kesehatan, Jakarta: Salemba Medika.

Devins, GM, Mandelssohn, DC, Barre, PE, Taub, K \& Binik, YM, 2005, Predialysis psyschoeducational intervention extends survival in CKD, American Journal of Kidney Disease, 1088-1098.

Dharma, K, 2011, Metodologi penelitian keperawatan: panduan melaksanakan dan menerapkan hasil penelitian, Jakarta: CV, Info Trans Medika.

Falvo, Donna R, 2005, Medical and psychososial aspect of chronic illness disability: $3^{\text {rd }}$ edition, Jones and Barlett Publisher Inc, USA.

Ghimire, Saurav,, Castelino, Ronald,, Lioufas, Nicole,, Peterson, Gregory,, Zaidi, Syed Tabish, 2015, Nonadherence to medication therapy in haemodialysis patients, PLOS One, 10(13), pp,1-19.

Ghozali, Imam, 2013, Structural equation modeling metode alternatif dengan partial least square, Semarang: Badan Penerbit UNDIP

Hidayat, AA, 2010, Metode penelitian kesehatan; paradigma kuantitatif, Surabaya: Health Books Publishing.

Hidayati, T, Yuningtyaswari, Sadewa, $A, H$, \& Soesatyo, M, H, 2014, The IGF-1 level of ESRD patients and it's risk factors, Indonesian Journal of Urology, 21(1), 2637 ,

Kallenbach, 2005, Review of hemodialysis for nursing and dialysis personnel $7^{\text {th }}$ edition, Elsevier Saunders, St,Louis Missouri

Kamaludin, R, \& Rahayu, E, 2009, Analisis faktor-faktor yang mempengaruhi kepatuhan asupan cairan pada pasien gagal ginjal kronik dengan hemodialisis di RSUD Prof, Dr, Margono Soekarjo Purwokerto, Jurnal Keperawatan Soedirman.

Kammerer, J, Garry, G, Hartigan, M, Carter, B,, \& Erlich, L, 2007, Adherence in patients on dialysis: startegies for success, Nephrology Nursing Journal, 34(5), 479-486,

Kessels, RP C, 2003, Patients's memory for medical information, Journal of the Royal Society of Medicine, 96(5), 219-222,

Kim, Y, Evangelista, LS, Phillips, LR, Pavlish, C \& Kopple, JD, 2010, The end-stage renal disease adherence questionnaire (ESRD$A Q$ ): testing the psychometric properties in patients receiving in-center hemodialysis, Nephrology Nursing Journal: 
Journal of the American Nephrology Nurses' Association, 37(4), 377-393.

Kurniasih, DP, Widyawati, IY \& Mariyanti, $\mathrm{H}$, 2015, Education in improving compliance fluid intake patients with chronic kidney disease (CKD) on hemodialysis, Critical and Medical Surgical Nursing Journal, 1-7.

Loghman-Adham, M, 2003, Medication noncompliance in patients with chronic disease: issues in dialysis and renal transplantation, The American Journal of Managed Care, 9(2), 155-171.

Lukens, E, \& McFarlane, W, 2004, Psychoeducation as evidence-based: consideration for practice, research and policy, Brief Treatment and Crisis Intervention, 4(3), 204-261.

Madeiro, A, C, Machado, P, D,, Bonfim, I, M, Braqueais, A, R, \& Lima, F, E, 2010, Adherence of Chronic Renal Insufficiency Patients to Hemodialysis, Acta Paul Enferm, 546-551.

Martin, L, R,, Williams, S, L,, Haskard, K, B,, \& DiMatteo, M, R, 2005, The challenge of patient adherence, Therapeutics and Clinical Risk Management, 3(1), 189-199.

McGillion, Arthur, H, Victor, J, C,, WattWatson, J,, \& Cosman, T, 2008, Effectiveness of psychoeducational intervention for improving symptoms, health-related quality of life, and psychological well being in patients with stable angina, Current Cardiology Reviews, 4(1), 1-11.

Munoz, E, B,, Dorado, M, F, Guerrero, J, E, \& Martinez, F, 2013, The effect of an educational intervention to improve patient adherence, Atencion Primaria, 367-375.

National Kidney Foundation, 2002, Kidney diseases outcome quality initiative advisory board: clinical practice guidelines for chronic kidney diseases, evaluation, classification, and stratification, $A m J$ Kidney,vol 39: 239-246.

Nursalam, 2014, Metodologi penelitian ilmu keperawatan pendekatan praktis, Jakarta: Salemba Medika.

Ogden, J, 2005, Adherence, behavior change, and visualization: A qualitative study of the experiences of taking an obesity medication, Journal of Psychosomatic Research, 61(10), pp,545-52.

Rahardjo, P, Susalit, E, \& Suhardjono, 2009, Hemodialisis, dalam A, W, Sudoyo, B, Setiyohadi, I, Alwi, M, Simadibrata, \& S, Setiati, Buku ajar ilmu penyakit dalam (hal, 179-180), Jakarta: Departemen IImu
Penyakit Dalam Fakultas Kedokteran Universitas Indonesia.

Rappof, Michael A, 1999, Adherence to pediatric medical regimens, Springer US.

Riskesdas, 2013, Riset kesehatan dasar, Jakarta: Badan Penelitian dan Pengembangan Kesehatan Kementerian Kesehatan RI.

Saran, R, Bragg-Gresham, J, Goodkin, D, Keen, M, Van Dijk, P, Kurokawa, K, 2003, Nonadherence in hemodialysis: association wiyh mortality, hospitalization, and practice patterns in the DOPPS, Kidney International, 64(1), 254-262.

Siswoyo, Suharto, \& Bakar, A, 2015, The effect of psychoeducation on knowledge, intention, and sick role behaviour, Jurnal Ners.

Stuart, GW, 2016, Prinsip dan praktik keperawatan kesehatan jiwa stuart (Indonesia ed,), Singapore: Elsevier.

Sugiyono, 2008, Metode penelitian kuantitatif, kualitatif dan $R \& D$, Bandung: Alfabeta

Sugiyono, 2015, Metode penelitian dan pengembangan, Bandung: Alfabeta,

Sukartini, T, 2015, Adherence improvement model based on king interaction system, The 6th International Nursing Conference Airlangga University (pp, 43-49), Surabaya: Salemba Medika.

Suwitra, K, 2009, Penyakit Ginjal Kronis, dalam A, W, Sudoyo, B, Setiyohadi, I, Alwi, M, Simadibrata, \& S, Setiati, Buku ajar ilmu penyakit dalam (hal, 571-573), Jakarta: Departemen IImu Penyakit Dalam Fakultas Kedokteran Universitas Indonesia.

Syarifuddin, 2010, Reliabilitas dan validitas, Yogyakarta: Pustaka Pelajar

Tomey, M, A, \& Alligood, M, R, 2006, Nursing theorist and their work, Missouri: Mosby Inc.

Walsh, D, 2010, The nursing mentor's handbook (2nd ed,), New York: Open University Press,

Wiffen, $\mathrm{P}$, Mitchell, M, Snelling, M, \& Stoner, N, 2007, Oxford handbook of clinical pharmacy, UK: Oxford University Press.

WHO, 2003, Adherence long-term therapies, Evidence for action, http://www,emro, who,int/ncd/publicity/adher ence-report-in-diabetic-patient/ diakses pada tanggal 07 Desember 2015

Yamin, S, Kurniawan, H, , 2011, Generasi baru mengolah data penelitian dengan partial least square path modeling, Jakarta: Penerbit Salemba Infotek 